\title{
GREXIT, BREXIT - THE FUTURE OF EUROPE
}

\author{
EDITOR'S PREFACE
}

"Grexit", a congenial portmanteau combining the English words "Greek" and "exit" was coined in February 2012. ${ }^{1}$ When the term was born, it was meant to convey the conclusion of cold-blooded market analysts who back then put the chances of Greece leaving the euro zone at 50 per cent over the following 18 months. Subsequently, the term quickly cemented itself into all European languages. If we can believe in the collective wisdom of Wikipedia, the term "Brexit" was born only three months later. ${ }^{2}$ As this Special Issue goes into print (end-2016), neither Grexit, nor Brexit happened in any legal sense, but the latter one seems to be more likely to happen nonetheless.

There has been an interesting epistemological paradox developing in front of our eyes. From the beginning of the euro zone crisis in December $2009^{3}$, the scholarly segment of economists have, by and large, all agreed that there is a sound line of arguments behind Grexit as a win-win strategy for the European Union as well as for the people of Greece. It must be noted however, that the very same people also noted the counter arguments against Grexit. By contrast, there was not a single serious economist deserving credit, who came forward with a theoretical reasoning to support Brexit. But, as we all know, the UK plebiscite

For the details behind this neologism, see Financial Times, 23 December 2012.

https://en.wikipedia.org/wiki/Brexit.

With the benefit of hindsight, the beginning of the euro zone crisis is dated from the announcement of the international ratings agency Fitch to downgrade Greece's debt and the subsequent confession of the newly elected Greek government about the true size of the country's debt. http://www.bbc.com/news/business-13856580 
on June 23, 2016 brought a clear majority vote for the "Leave" supporters - i.e. the question of Brexit was politically decided. So much for the opinion-forming influence of economists.

With due modesty, the academic segment of the profession and the faculties of macroeconomic departments in particular have to acknowledge that the starting problem of the euro zone crisis happened in a way which ran contrary to the quintessential spirit of macroeconomics, namely that "only size matters". If something is relatively small, it cannot influence the real (macro) economy - this is the idea which separates microeconomics from macroeconomics. The optimum currency area (OCA) theory, on which the euro is based, also rests on the same foundation. It was previously believed that as long as the large economies of the euro zone fulfilled the OCA criteria, the common currency was unshakeable. With hindsight, it then became clear that the actual behaviour of financial markets differs fundamentally from the underlying assumptions of OCA which was, in spite of its name, essentially a macroeconomic concept and not a financial one. From experience, we now know that smaller economies, smaller markets and smaller banks can also cause system-wide troubles through the mechanisms of bank-run and cross-country contagion. Nevertheless, the euro zone was designed and engineered, the lessons of past financial crises were simply not factored into the blueprints. ${ }^{4}$ Only a few weeks after the first Greek financial panic, market concern started to build around all the heavily indebted smaller countries - Portugal, Ireland, and Spain.

This thematic Special Issue of Acta Oeconomica, the third of its kind ${ }^{5}$, is devoted to the discussion pertaining to the future of the European Union and in a broader sense, the future of Europe. To the great surprise and pleasure of this Editor, the 8 papers, independently commissioned, don't really contain overlaps. The contributors miraculously divided the issues as authors of a well-designed monograph would do. Each of them elaborated different sub-questions in greater details. Their

$4 \quad$ As a matter of fact, the ex-ante critics of the common European currency focused on the shortcomings of the European integration model arising from the lack of a common fiscal policy. See e.g. Rudiger Dornbusch: Euro Fantasies: Common Currency as Panacea. Foreign Affairs, September/October 1996.

5 The first book-size publication in our series (Vol. 64. Special Issue 1, 2014) was devoted to the 25th Anniversary of Post-Socialist Transition. It was essentially a celebratory collection of 8 papers with a strong emphasis on the historical economic achievements and the peaceful political transition. A year later, Vol. 65. Special Issue 1, 2015 carried a more sober title, Transition Economies in Trouble. With 9 commissioned papers we covered 14 countries. Our sad conclusion was that the catching-up process for these economies has turned out to be much slower than generally expected. Furthermore, and not independently from the economic performance, many countries have failed to create a democratic political system. 
conclusions, not surprisingly, are all formulated in a very cautious way. Nobody dares to predict when and how Brexit will eventually happen - if at all.

Let me end this short introduction on a brave, optimistic tone. It is a fact, that the common currency, the euro, was already saved. The Greek economy is already beyond the most difficult part of adapting her economic and political institutions to the common norms of the EU. The other problem countries, mentioned above, are also heading in the right direction. I also believe that the euro zone and the EU will stay together, with Brexit not actually happening in the end. Paradoxically, the withdrawal of the Brexit referendum decision might be somehow linked to the patriotic-nationalistic fever of the various people of the British Isles - the Scots, the Northern Irish and the British people themselves. They can stay together, if they all stay within the existing arrangements of the European Union. The rest is political craftsmanship.

The aim of this volume was to provide a broad picture of the events which have led to the culmination of crises in late-2009 and mid-2016. After two, three or five years, future readers of this journal's hard copy in libraries or its internet archived version will find out how relevant our authors' analysis was.

Budapest, 18 October 2016.

Peter Mihalyi

Editor-in-Chief 